\title{
The Shola (Tropical Montane Forest)-Grassland Ecosystem Mosaic of Peninsular India: A Review
}

\author{
Milind Bunyan ${ }^{1}$, Sougata Bardhan ${ }^{2}$, Shibu Jose ${ }^{2 *}$ \\ ${ }^{1}$ School of Forest Resources and Conservation, Gainesville, USA; ${ }^{2}$ The Center for Agroforestry, School of Natural Resources, 203 \\ Anheuser-Busch Natural Resources Building, University of Missouri, Columbia, USA.

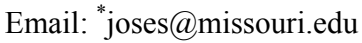

Received August $17^{\text {th }}, 2012$; revised September $24^{\text {th }}, 2012$; accepted October $10^{\text {th }}, 2012$

\begin{abstract}
Tropical montane forests (alternatively called tropical montane cloud forests or simply cloud forests) represent some of the most threatened ecosystems globally. Tropical montane forests (TMF) are characterized and defined by the presence of persistent cloud cover. A significant amount of moisture may be captured through the condensation of cloud-borne moisture on vegetation distinguishing TMF from other forest types. This review examines the structural, functional and distributional aspects of the tropical montane forests of peninsular India, locally known as shola, and the associated grasslands. Our review reveals that small fragments may be dominated by edge effect and lack an "interior" or "core", making them susceptible to complete collapse. In addition to their critical role in hydrology and biogeochemistry, the shola-grassland ecosystem harbor many faunal species of conservation concern. Along with intense anthropogenic pressure, climate change is also expected to alter the dynamic equilibrium between the forest and grassland, raising concerns about the long-term sustainability of these ecosystems.
\end{abstract}

Keywords: Shola Forests; Western Ghats; GIS; Biodiversity; Species Composition; Shola Fragments

\section{Introduction}

Tropical montane forests (alternatively called tropical montane cloud forests or simply cloud forests) represent some of the most threatened ecosystems globally. Tropical montane forests (TMF) are characterized and defined by the presence of persistent cloud cover. A significant amount of moisture may be captured through the condensation of cloud-borne moisture on vegetation distinguishing TMF from other forest types. Bruijzneel and Hamilton [1] described five kinds of TMF. Four of these, i.e. lower montane forest, lower montane cloud forest, upper montane cloud forest and subalpine cloud forest, are based on elevation and tree height whereas the last one an azonal low elevation dwarf cloud forest.

Elevations at which TMF are found, vary with mountain range size and insularity or proximity to coast. Due to the mass-elevation effect (also known as the Massenerhebung effect), larger mountain ranges permit the extension of the altitudinal range of plant species. Similarly, higher humidity levels near coastal mountains enable the formation of clouds at lower altitudes. On insular or coastal mountain ranges, TMF has been reported

"Corresponding author. from elevations as low as $500 \mathrm{~m}$ (Bruijzneel and Hamilton, 2000). As elevation increases, tree height in TMF reduces and leaf thickness and complexity in tree architecture increases. Other distinctive features of TMF are the prolific growth of epiphytes and mosses and the lack of vertical stratification. TMF soils are typically clay-rich, have low $\mathrm{pH}$, abundant organic matter and are often nutritionally poor. TMF are characterized by high levels of endemism driven by the limited availability of habitat [2]. Located in the headwater catchments of seasonal or perennial streams, TMF provides often undervalued ecosystem services to downstream communities.

Within the Western Ghats-Sri Lanka (WGSL) biodiversity hotspot [3], TMF occurs as a mosaic of forests (locally and hereafter sholas) and grasslands and is commonly referred to as the shola-grassland ecosystem. With limited exceptions [4,5], data from the shola-grassland ecosystem mosaic are rarely included in biome-wide popular [1] as well as academic [2,6] synopses of scientific literature. As such, this document aims to provide a synthesis of current research and the state of knowledge of the shola-grassland ecosystem from peer-reviewed literature published on tropical montane forests in the WGSL biodiversity hotspot. Additionally, a synopsis of research on the sholas of Kerala was also reviewed [7]. 


\section{The Shola-Grassland Ecosystem Mosaic}

\subsection{Background}

The Western Ghats located in the WGSL hotspot are a $1600 \mathrm{~km}$ long mountain $\left(160,000 \mathrm{~km}^{2}\right)$ chain in southern India. Located above $1700 \mathrm{~m}$, the shola-grassland ecosystem mosaic consists of rolling grasslands with shola fragments restricted to sheltered folds and valleys in the mountains separated from the grasslands with a sharp edge. Since, sholas frequently have persistent cloud cover they can be classified as lower montane cloud forest or upper montane cloud forest depending on elevation [1]. Ecologists and foresters have been puzzled over the pattern of the shola-grassland ecosystem mosaic for decades. While some of the earliest scientific descriptions of the shola-grassland ecosystem described the mosaic as dual climax [8], proponents of the single climax concept [9] argued that the forests represented a biotic $[10,11]$ or edaphic climax [12]. A $\delta \mathrm{C} 13$ analysis of peat samples from shola fragments in the Nilgiris indicated that shola and grasslands have undergone cyclical shifts in dominant vegetative cover. Arid conditions from 20,000 $16,000 \mathrm{yr} \mathrm{BP}$ led to predominance of $\mathrm{C} 4$ vegetation. This was followed by a wetter phase which peaked around $11,000 \mathrm{yr}$ BP leading to a dominance in $\mathrm{C} 3$ vegetation. The weakening of the monsoon around $6000 \mathrm{yr}$ BP led to the expansion of the $\mathrm{C} 4$ vegetation again and the establishment of the current pattern, although a brief warm, wet phase around $600-700 \mathrm{yr}$ BP also occurred [13].

\subsection{What Is Not a Shola?}

Arguably, the shola-grassland ecosystem mosaic is among the most distinct ecosystem types in the WGSL biodiversity hotspot. Although, sholas are typically seen at elevations $\geq 1700 \mathrm{~m}$, sholas at elevations as low as $1050 \mathrm{~m}$ have been studied by ecologists [14]. In the Anamalais and Nilgiris, the shola-grassland mosaic is characteristically patchy. Often though, shola fragments are linear strips that may or may not be contiguous with lowland evergreen forest which contain a different suite of species. While species dominance patterns are distinct from lowland forest, sholas of different regions exhibit little similarity in species composition.

Yet, physiognomic characteristics of sholas are consistent. Sholas consist of profusely branched, stunted trees (rarely exceeding $15 \mathrm{~m}$ ) with prolific epiphytic growth. In order to distinguish shola from non-shola forest types, despite the varied conditions under which they are found, we propose that ecologically, a shola be defined as a high elevation $(\geq 1700 \mathrm{~m}$ ) stunted forest with distinct physiognomy. Studies on sholas at elevations below $1700 \mathrm{~m}$ should be restricted to shola fragments surrounded by grasslands. Indeed, in plots located at lower elevations, Sudhakara et al. [14] recorded families uncommon to sholas but common to lowland forests (Bombaceae, Clusiaceae, Dichapetalcaeae).

\section{Flora, Fauna, and the Soil}

In this section we will discuss about the different environmental and ecosystem parameters generally observed in the shola grassland ecosystem. Flora, fauna, hydrology, and soil nutrient cycling have been discussed in great detail. We have also reviewed the dynamics of edge effect in the shola-grassland ecosystem.

\subsection{Flora}

Since Thomas and Palmer [15] have provided a comprehensive review of current research on grasslands in the shola-grassland ecosystem mosaic, we will restrict this section to reviewing work on the shola vegetation only. Shola fragments contain species of both tropical and temperate affinities. Also, the grasslands of the Western Ghats show more biogeographic similarity with Western Himalayan species than TMF in Sri Lanka [16]. Phytogeographical analysis of shola genera reveals that genera found on the fringes of shola fragments and as isolated trees on grasslands are typically temperate (Rubus, Daphiphyllum and Eurya) or sub-tropical (Rhododendron, Berberis, Mahonia are Himalayan) in origin. Species within shola fragments on the other hand are IndoMalayan or Indian (rarely Paleotropical) in origin $[17,18]$. Overstory species in the shola are dominated by members of Lauraceae, Rubiaceae, Symplocaceae, Myrtaceae, Myrsinaceae and Oleaceae while dicotyledonous understory species are dominated by Asteraceae, Fabaceae, Acanthaceae, $[19,20]$. Dominant monocot species in the understory include members of Poaceae, Orchidaceae \& Cyperaceae [20]. Along edge-interior gradients in shola fragments, species were found to be significantly influenced by soil moisture (overstory and understory) and soil nitrogen (understory only) [21]. However this study was based on observations from a single shola patch.

Based on our knowledge of species-area curves, we might expect that the limited availability of suitable habitat for shola species within the shola-grassland ecosystem mosaic would limit $\alpha$-diversity. However estimates for $\alpha$-diversity are highly variable. Estimates for Shannon-Weiner's diversity index (H') range from 4.71 [14] to 0.87 [22]. Estimates for endemism are also highly variable-from $19.5 \%$ to $83.3 \%$ [18]. Historically, the regeneration of arborescent flora in shola fragments had been expressed as a concern [23]. A series of studies now indicate that shola species show adequate regeneration under natural conditions [12,20]. Additionally, germination rates as high as $95 \%$ have been recorded for shola species in germination trials [24]. 
As with other TMF, shola fragments exhibit prolific epiphytic growth. Studies in TMF have shown that epiphytic species may constitute up to $25 \%$ of all biomass in tropical montane forests [25]. They also provide microhabitats for invertebrates and amphibians [26], store significant amounts of water [27] and influence nutrient cycling [26]. However, given the extent of scientific literature on arborescent flora in the shola [7,19,21], very limited work exists on epiphytes in the shola-grassland ecosystem mosaic [28]. Similarly, very few studies have quantified productivity in the shola-grassland ecosystem mosaic. In a comparison of net primary productivity (NPP) patterns of exotic plantations and native shola forest, NPP and biomass of older exotic plantations (Eucalytpus globulus and Pinus patula) were significantly higher than that of shola species. However this was at the cost of lowering of NPP and biomass in the understory in exotic plantations, possibly due to allelopathic inhibition [29].

\subsection{Fauna}

The shola-grassland ecosystem mosaic provides habitat for many faunal species of conservation concern including the tiger (Panthera tigris tigris), dhole (Cuon alpinus), gaur (Bos gaurus gaurus) Nilgiri langur (Trachypithecus johnii) and Nilgiri marten (Martes gwatkinsii). Endemic to the ecosystem-mosaic is the Nilgiri tahr (Niligiritragus hylocrius) which has been studied meticulously over the years [30-34]. Although considered a flagship species for the ecosystem, uncertainty over population estimates persists [35] even as the population shows a declining trend [36].

Faunal species too have been observed to mirror the shola-grassland ecosystem mosaic pattern through habitat preferences. Small mammal communities in the Nilgiris (two species of the nine recorded), showed a high degree of preference for either shola or grassland despite a lack of resource-driven interspecific competition. However, these patterns were obscured in exotic plantations [37]. Strong habitat selection patterns have also been observed in avian species in the shola-grassland ecosystem mosaic. Habitat suitability models for the Nilgiri laughing thrush (Garrulax cachinnans) indicate that habitat use typically restricted to shola cover might extend to exotic plantations (unsuitable habitat) when located near shola fragments [38]. Other avian species such as the black and orange flycatcher (Ficedula nigrorufa) have also been known to show a strong preference for shola cover.

Other than those mentioned above, inventories have also been conducted on amphibian, avian, invertebrate and fish species [7,39]. However with the exception of the Nilgiri tahr, the body of scientific literature on faunal species in the shola-grassland ecosystem mosaic is limited (Table 1).

Table 1. Faunal species richness in tropical montane forests.

\begin{tabular}{|c|c|c|c|c|c|c|c|}
\hline Cover class & Site & Elevation & Taxa & Species richness & $\begin{array}{c}\text { Species } \\
\text { diversity (H') }\end{array}$ & $\begin{array}{l}\text { Percent } \\
\text { endemism }\end{array}$ & Source \\
\hline \multirow{7}{*}{$\begin{array}{c}\text { Tropical } \\
\text { montane } \\
\text { forest/Shola }\end{array}$} & \multirow{2}{*}{ Mannavan shola } & $1600-1700$ & Birds & 30 & - & 20 & Nameer (2001) \\
\hline & & $2000-2100$ & Birds & 40 & - & 23 & Nameer (2001) \\
\hline & Kerala & - & Fish & 24 & - & - & Ghosh (2001) \\
\hline & Chembra & 1700 & Insects & 81 & 4.22 & - & Mathew et al. (2001) \\
\hline & \multirow{3}{*}{ Nilgiris } & $1800-2500$ & Small mammals & 8 & - & - & Shanker (2001) \\
\hline & & \multirow{2}{*}{$2000-2050$} & Bacteria & 93.22 & - & - & Venkatachalam et al. (2007) \\
\hline & & & Fungi & 7.78 & - & - & Venkatachalam et al. (2007) \\
\hline \multirow{3}{*}{ Grassland } & \multirow{3}{*}{ Nilgiris } & $1800-2500$ & Small mammals & 3 & - & - & Shanker (2001) \\
\hline & & \multirow{2}{*}{$2000-2050$} & Bacteria & $30.31^{\dagger}$ & - & - & Venkatachalam et al. (2007) \\
\hline & & & Fungi & $8.89^{*}$ & - & - & Venkatachalam et al. (2007) \\
\hline \multirow{3}{*}{$\begin{array}{l}\text { Plantation } \\
\text { (Mixed) }\end{array}$} & \multirow{3}{*}{ Nilgiris } & $1800-2500$ & Small mammals & 3 & - & - & Shanker (2001) \\
\hline & & \multirow{2}{*}{$2000-2050$} & Bacteria & $37.53^{\dagger}$ & - & - & Venkatachalam et al. (2007) \\
\hline & & & Fungi & $7.66^{*}$ & - & - & Venkatachalam et al. (2007) \\
\hline \multirow{3}{*}{$\begin{array}{l}\text { Plantation } \\
\text { (Tea) }\end{array}$} & \multirow{3}{*}{ Nilgiris } & $1800-2050$ & Small mammals & 4 & - & - & Shanker (2001) \\
\hline & & \multirow{2}{*}{$2000-2050$} & Bacteria & $18.54^{\dagger}$ & - & - & Venkatachalam et al. (2007) \\
\hline & & & Fungi & $5.78^{*}$ & - & - & Venkatachalam et al. (2007) \\
\hline
\end{tabular}

$\S_{0}-10 \mathrm{~cm},{ }^{*} 0-15 \mathrm{~cm},{ }^{\#} 0-20 \mathrm{~cm} ;{ }^{+}$Undefined (depth of O horizon); ${ }^{\mathrm{a}}$ Jeeva and Ramakrishnan 1997; ${ }^{\dagger}$ Percent concentration. 


\subsection{Hydrology}

Globally, tropical montane forests have been shown to significantly influence ecosystem hydrology and biogeochemistry [1]. In addition to providing cover and reducing erosion potential, net precipitation (precipitation reaching the ground) under tropical montane forests is often greater than $100 \%$ (and as high as $180 \%$ ). This has been attributed to condensation of wind-driven fog on tree crowns (termed fog drip). In areas of low precipitation such as the Canary Islands, interception of cloud water can double annual precipitation [40]. Protection of tropical montane habitat serves the purpose of hydrological regulation for downstream consumers also. This is especially significant in the Western Ghats where major rivers originating in the shola-grassland ecosystem mosaic provide hydrological services to consumers. A study by Krishnaswamy et al. [41] demonstrated that individual rainfall events could contribute as much as $20 \%-30 \%$ of the annual sediment load of $239-947$ $\mathrm{Mg} \cdot \mathrm{km}^{-2}$ [41]. Other studies report significantly lower sediment load estimates $\left(30-97 \mathrm{Mg} \cdot \mathrm{km}^{-2} \cdot \mathrm{year}^{-1}\right)$ from other areas $[42,43]$ with as much as $90 \%$ of the annual runoff occurring during the SW Monsoon [42].

\subsection{Soils and Nutrient Cycling}

Soils in the shola-grassland ecosystem mosaic are granitic or metamorphic gneisses in origin. They are of varying depth, ranging from deep [8] to shallow, stony soils [44]. Typically, soils are shallower in the grasslands as compared to shola soils and are more prone to soil moisture loss. During the dry season, shola soils have been shown to retain as much as twice the soil moisture in the surrounding grasslands [42]. Shola and grassland soils also differ nutritionally. Total $\mathrm{N}$, available $\mathrm{P}$ and $\mathrm{K}$ are higher in the sholas as compared to adjoining grasslands. Though this could be attributed to higher litter decomposition and nutrient recycling rates in the sholas, these differences are rarely significant. Jose et al. [12] report organic carbon content in shola surface soils that are comparable to those recorded in TMF in Ecuador. These values though are much higher than those recorded by other authors for surface soils under varied types of cover in the shola-grassland ecosystem mosaic (Table 2). No soil-depth related trends have been reported for plant essential micronutrients ( $\mathrm{Cu}, \mathrm{Mn}, \mathrm{Zn}$ and $\mathrm{Fe}$ ) in sholas or adjacent grasslands although differences between sholas and adjacent grasslands have been observed [45]. Shola soils have higher soil nutrient pools than those under exotic plantations of blue gum (E. globulus) or tea ( $\mathrm{Ca}$ mellia sinensis) [29,46]. Nutrient cycling under natural shola vegetation has also been described as steady state and less likely to suffer losses to leaching since the return through leaf litter is low [29].
Trends in biogeographical affinities have also been recorded for soil microflora. Though most soil fungal species recorded in soils in the shola-grassland ecosystem mosaic are cosmopolitan in distribution, the prevalence of the genus Penicillium is characteristic of temperate forests [47] Soil fungal species diversity is comparable between shola fragments and grasslands (H'SHOLA $=4.18$, H'GRASSLAND = 4.18) albeit highly habitat specific [47]. Shola soils also had significantly higher soil bacterial and actinomycetes populations than grassland or plantation soils while fungal populations were highest in grassland soils. Plantation soils under tea, blue gum and black wattle (Acacia mearnsii) were also consistently observed to have lower soil microbial biomass than soils under native vegetation [46].

\subsection{The Shola-Grassland Edge}

The current dynamic equilibrium between insular shola fragments and grasslands is indicative of the existence of alternate stable states enforced by environmental parameters $[48,49]$. A change in parameters causes a shift in dominant cover (Figure 1). Applied to the shola-grassland ecosystem mosaic, these parameters might include frost [8,50,51], fire [10], grazing [10,11], soil nutrient status [12], soil depth (Ganeshaiah, personal communication), wind [52] and illegal harvesting [44]. The persistence of the mosaic in areas relatively free of anthropogenic grazing and illegal harvesting in some protected

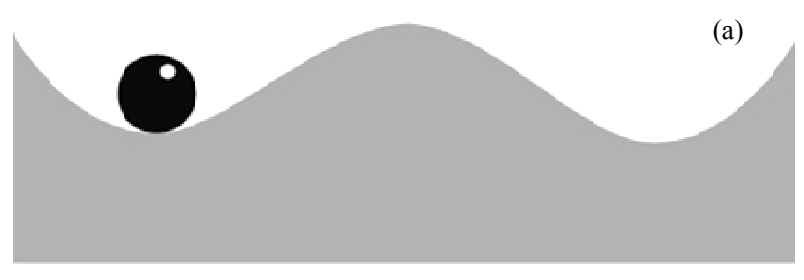

(b)

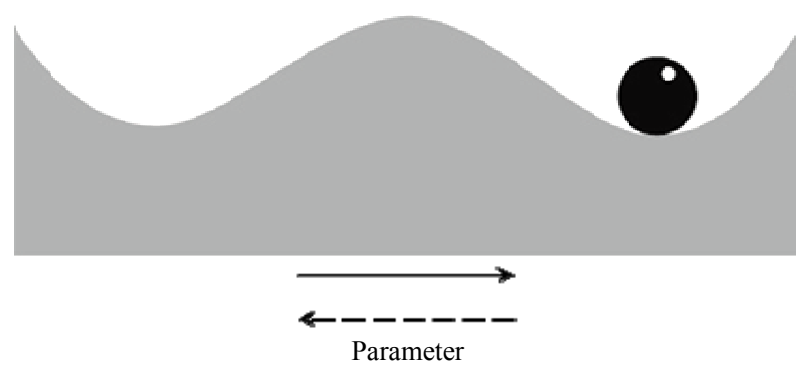

Figure 1. Alternate stable state diagram for the sholagrassland ecosystem mosaic. A change in parameter (e.g. frost, fire) can cause a shift in communities. An increase in fire occurrence can move the dominant community (ball) from shola (a) to grassland (b). A reversal of the parameter can cause the community to return to its original state (along the dashed line). 
Table 2. Surface soil chemical characteristics in tropical montane forests.

\begin{tabular}{|c|c|c|c|c|c|c|c|c|c|}
\hline \multirow{3}{*}{ Cover class } & \multirow{3}{*}{ Site } & \multicolumn{7}{|c|}{ Soil nutrients } & \multirow{3}{*}{ Authors } \\
\hline & & \multirow[t]{2}{*}{$\mathrm{pH}$} & \multirow{2}{*}{$\begin{array}{l}\mathrm{C} \\
\%\end{array}$} & $\mathrm{~N}$ & $\mathrm{P}$ & K & $\mathrm{Ca}$ & $\mathrm{Mg}$ & \\
\hline & & & & & & \multicolumn{3}{|l|}{$\mathrm{kg} \cdot \mathrm{ha}^{-1}$} & \\
\hline \multirow{6}{*}{$\begin{array}{l}\text { Tropical montane } \\
\text { forest/Shola }\end{array}$} & Brahmagiri & $5.60^{*}$ & $2.80^{*}$ & $0.18^{*} \ddagger$ & & $0.02^{*}$ & $0.14^{*}$ & $0.02^{*}$ & $\begin{array}{l}\text { Thomas and Sankar } \\
\qquad(2001)\end{array}$ \\
\hline & Nilgiri hills & $5.44^{\#}$ & $1.65^{\#}$ & $306.91^{\#}$ & $7.27^{\#}$ & $138.43^{\#}$ & $183.40^{\S a}$ & $6.8^{\S a}$ & $\begin{array}{c}\text { Venkatachalam et al. } \\
\text { (2007) }\end{array}$ \\
\hline & Eravikulam & - & $22.48^{\#}$ & $1.21^{\# \neq}$ & $0.02^{\# \neq}$ & $0.01^{\#+}$ & - & - & Jose et al. (1994) \\
\hline & $\begin{array}{l}\text { Ecuador } \\
(1960 \mathrm{~m})\end{array}$ & $4.60^{+}$ & $39.00^{+}$ & $2.10^{+\ddagger}$ & $0.87^{+\ddagger}$ & $0.35^{+\ddagger}$ & $0.36^{+\ddagger}$ & $0.14^{+\star}$ & Wilcke et al. (2008) \\
\hline & $\begin{array}{l}\text { Ecuador } \\
(2090 \mathrm{~m})\end{array}$ & $3.90^{+}$ & $48.50^{+}$ & $1.80^{+\ddagger}$ & $0.57^{+\ddagger}$ & $0.11^{+\ddagger}$ & $0.51^{+\ddagger}$ & $0.06^{+\$}$ & Wilcke et al. (2008) \\
\hline & $\begin{array}{l}\text { Ecuador } \\
(2450 \mathrm{~m})\end{array}$ & $4.40^{+}$ & $35.60^{+}$ & $1.20^{+\ddagger}$ & $0.34^{+\ddagger}$ & $0.11^{+\ddagger}$ & $0.18^{+\ddagger}$ & $0.03^{+\neq}$ & Wilcke et al. (2008) \\
\hline \multirow{3}{*}{ Grassland } & Brahmagiri & $5.00^{*}$ & $2.40^{*}$ & $0.04^{*+}$ & & $0.01^{* *}$ & $0.03^{* \neq}$ & $0.02^{* \dagger}$ & $\begin{array}{l}\text { Thomas and Sankar } \\
\qquad(2001)\end{array}$ \\
\hline & Nilgiri hills & $4.04^{\#}$ & $0.87^{\#}$ & $132.92^{\#}$ & $1.84^{\#}$ & $70.68^{\#}$ & - & - & $\begin{array}{l}\text { Venkatachalam et al. } \\
\text { (2007) }\end{array}$ \\
\hline & Eravikulam & & $18.88^{\#}$ & & & & & & Jose et al. (1994) \\
\hline $\begin{array}{c}\text { Plantation } \\
\text { (Eucalyptus globulus) }\end{array}$ & \multirow{4}{*}{ Nilgiri hills } & - & - & $97.50^{\S}$ & $10.60^{\S}$ & $74.50^{\S}$ & $123.60^{\S}$ & $45.70^{\S}$ & $\begin{array}{c}\text { Jeeva and Ramakrishnan } \\
\text { (1997) }\end{array}$ \\
\hline $\begin{array}{c}\text { Plantation } \\
\text { (Pinus patula) }\end{array}$ & & - & - & $188.50^{\S}$ & $22.70^{\S}$ & $109.80^{\S}$ & $158.80^{\S}$ & $127.90^{\S}$ & $\begin{array}{c}\text { Jeeva and Ramakrishnan } \\
\text { (1997) }\end{array}$ \\
\hline Plantation (Mixed) & & $4.45^{\#}$ & $1.10^{\#}$ & $199.99^{\#}$ & $3.67^{\#}$ & $88.65^{\#}$ & - & - & $\begin{array}{l}\text { Venkatachalam et al. } \\
\text { (2007) }\end{array}$ \\
\hline Plantation (Tea) & & $4.06^{\#}$ & $0.98^{\#}$ & $205.32^{\#}$ & $4.14^{\#}$ & $100.19^{\#}$ & - & - & $\begin{array}{l}\text { Venkatachalam et al. } \\
\text { (2007) }\end{array}$ \\
\hline
\end{tabular}

${ }_{0}^{s_{0}}-10 \mathrm{~cm},{ }^{*} 0-15 \mathrm{~cm},{ }^{\sharp} 0-20 \mathrm{~cm} ;{ }^{+}$Undefined (depth of O horizon); ${ }^{\mathrm{a}}$ Jeeva and Ramakrishnan 1997; ${ }^{\star}$ Percent concentration.

areas make these two parameters tenuous for explaining the pattern. Although some authors have observed grassland soils to be shallower than shola soils [12]; others [45] did not find a consistent trend. Moreover, shola species have been observed growing on shallow soils too [8]. Grassland fires are used as a management tool in the shola-grassland ecosystem mosaic to reduce fuel loads [16] and in some instances a protective belt is cleared of vegetation around the shola before the grasslands are fired to preclude fire from the shola (personal observation). These fires could act as an effective deterrent in the colonization of the grasslands by shola species. Additionally, a study on vegetation fires during the dry season (February-June) of 2006 revealed that tropical montane forests in the Indian subcontinent accounted for $8.07 \%$ (92 fires) of all fires [53]. Although current understanding points to fire as the dominant factor responsible for the maintenance of the edge, ambiguity remains.

\section{Conclusions}

Historically, the shola-grassland ecosystem mosaic has undergone extensive habitat loss. Plantations of exotic tree species were established in the grasslands aimed at augmenting timber production as early as 1843 [54] with further introductions in 1870 in the Palni hills [55]. Plantation programs were expanded under colonial rule to establish extensive tea plantations in the mosaic. Post independence, tree plantation programs also received national (federal) budgetary support [56]. Significant populations of invasive shrubs and herbs (Eupatorium glandulosum, Ulex europaeus and Cytisus scoparius) in the shola-grassland ecosystem mosaic were reported by early researchers [10,57]. This list continues to expand as new exotic species (e.g. Calceolaria mexicana, Erigeron mucronatum) have recently been reported from the ecosystem [58].

To our knowledge only one study to date quantifies edge effects in the shola-grassland ecosystem mosaic [21]. Unlike the sholas, fragmentation in other tropical montane forests (such as the neotropics) is often a result of recent anthropogenically induced pressures (e.g. fire, conversion to pasture). As such, edge effect studies in the 
shola-grassland ecosystem might be especially insightful since species in older fragments have had time to equilibrate with fragmentation-induced pressures $[59,60]$. Fragmentation studies often observe a proportional increase in area under edge influence with diminishing fragment size. Small fragments may then be dominated by edge effect and lack an "interior" or "core", making them susceptible to complete collapse [61]. An edge effect study in the shola-grassland ecosystem would help us understand patterns in small fragments since shola fragments in the shola-grassland ecosystem mosaic are often small $(\sim 1 \mathrm{ha})$.

Threats to the mosaic today include the harvesting of shola species to meet biomass and fuelwood requirements and cattle grazing [62]. In areas adjoining settlements, these threats can be significantly amplified altering patterns in species richness and dominance [63]. The WGSL biodiversity hotspot is likely to undergo extinctions in plant and vertebrate species due to the limited availability of habitat [64]. Further, globally, TMF experience higher annual loss in habitat than any other tropical forest biome (FAO 1993). As Sukumar et al. [13] suggest, climate change is expected to alter the dynamic equilibrium between the forest and grassland through a reduction in the incidence of frost coupled with the strengthening of the monsoon which would select for $\mathrm{C}_{3}$ species. Responding to these threats appropriately requires the application of current state of knowledge coupled with an identification of gaps in our knowledge base.

\section{REFERENCES}

[1] L. A. Bruijnzeel and L. S. Hamilton, "Decision Time for Cloud Forests," IHP Humid Tropics Programme Series, No. 13, UNESCO, Paris, 2000.

[2] P. Bubb, I. May, L. Miles and J. Sayer, "Cloud Forest Agenda," UNEP-WCMC, Cambridge, 2004. http://www.unep-wcmc.org/resources/publications/UNEP _WCMC_bio_series/20.htm

[3] N. Myers, R. A. Mittermeier, C. G. Mittermeier, G. A. B. da Fonseca and J. Kent, "Biodiversity Hotpots for Conservation Priorities," Nature, Vol. 491, No. 333, 2000, pp. 853-858. doi:10.1038/35002501

[4] W. L. Werner, "Biogeography and Ecology of the Upper Montane Rain Forest of Sri Lanka (Ceylon)," In: L. S. Hamilton, J. O. Juvik and F. N. Scatena, Eds., Ecological Studies 110: Tropical Montane Cloud Forests, SpringerVerlag, New York, 1995, pp. 343-352. doi:10.1007/978-1-4612-2500-3_25

[5] H. Somanathan and R. M. Borges, "Influence of Exploitation on Population Structure, Spatial Distribution and Reproductive Success If Dioecious Species in Fragmented Cloud Forest in India," Biological Conservation, Vol. 80, 2000, pp. 9-15.

[6] L. S. Hamilton, J. O. Juvik and F. N. Scatena, "Ecological
Studies 110: Tropical Montane Cloud Forests," SpringerVerlag, New York, 1995. doi:10.1007/978-1-4612-2500-3

[7] K. K. N. Nair, S. K. Khanduri and K. Balasubramanayam, "Shola Forests of Kerala: Environment and Biodiversity," Kerala Forest Research Institute, Peechi, 2001.

[8] C. R. Ranganathan, "Studies in the Ecology of the Shola Grassland Vegetation of the Nilgiri Plateau," Indian Forester, Vol. 64, 1938, pp. 523-541.

[9] F. E. Clements, "Nature and Structure of Climax," Journal of Ecology, Vol. 24, No. 1, 1936, pp. 252-284. doi: $10.2307 / 2256278$

[10] N. L. Bor, "The Vegetation of the Nilgiris," Indian Forester, Vol. 64, 1938, pp. 600-609.

[11] W. A. Noble, "The Shifting Balance of Grasslands, Shola Forests and Planted Trees on the Upper Nilgiris, Southern India," Indian Forester, Vol. 93, 1967, pp. 691-693.

[12] S. Jose, A. Sreepathy, B. Mohan Kumar and V. K. Venugopal, "Structural, Floristic and Edaphic Attributes of the Shola-Grassland Forests of Eravikulam in Peninsular India," Forest Ecology and Management, Vol. 65, No. 2-3, 1994, pp. 279-291. doi:10.1016/0378-1127(94)90176-7

[13] R. Sukumar, H. S. Suresh and R. Ramesh, "Climate Change and Its Impact on Tropical Montane Ecosystems in Southern India," Journal of Biogeography, Vol. 22, No. 2-3, 1995, pp. 533-536. doi:10.2307/2845951

[14] K. Sudhakara, "Inventory and Computerized Herbarium of Higher Plants in the Sholas of Munnar, Idukki District," In: K. K. N. Nair, S. K. Khanduri and K. Balasubramanayam, Eds., Shola Forests of Kerala: Environment and Biodiversity, Kerala Forest Research Institute, Peechi, 2001, pp. 179-208.

[15] S. M. Thomas and M. W. Palmer, "The Montane Grasslands of the Western Ghats, India: Community Ecology and Conservation," Community Ecology, Vol. 8, No. 1, 2007, pp. 67-73. doi:10.1556/ComEc.8.2007.1.9

[16] P. V. Karunakaran, G. S. Rawat and V. K. Uniyal, "Ecology and Conservation of the Grasslands of Eravikulam National Park and the Western Ghats," Wildlife Institute of India, Dehradun, 1998.

[17] H. S. Suresh and R. Sukumar, "Phytogeographical Affinities of Flora of Nilgiri Biospehere Reserve," Rheedea, Vol. 9, No. 1, 1999, pp. 1-21.

[18] K. K. N. Nair and A. R. R. Menon, "Endemic Arborescent Flora of the Sholas of Kerala and Its Population and Regeneration Status," In: K. K. N. Nair, S. K. Khanduri and K. Balasubramanayam, Eds., Shola Forests of Kerala: Environment and Biodiversity, Kerala Forest Research Institute, Peechi, 2001. pp. 209-236.

[19] P. Davidar, D. Mohandass and S. L. Vijayan, "Floristic Inventory of Woody Plants in a Tropical Montane Forest in the Palni Hills of the Western Ghats, India," Tropical Ecology, Vol. 48, No. 1, 2007, pp. 15-25.

[20] K. Swarupanandan, N. Sasidharan, K. C. Chacko and S. C. Basha, "Floristic and Ecological Studies on the Sholas of Idukki District,” In: K. K. N. Nair, S. K. Khanduri and K. Balasubramanayam, Eds., Shola Forests of Kerala: Environment and Biodiversity, Kerala Forest Research Institute, 
Peechi, 2001, pp. 259-286.

[21] S. Jose, A. R. Gillespie, S. J. George and M. K. Kumar, "Vegetation Response along Edge-Interior Gradients in a High Altitude Tropical Forest in Peninsular India," Forest Ecology and Management, Vol. 87, No. 1-3, 1996, pp. 51-62. doi:10.1016/S0378-1127(96)03836-4

[22] K. S. Murali, R. S. Shetty, K. N. Ganeshaiah and R. U. Shaanker, "Does Forest Type Classification Reflect Spatial Dynamics of Vegetation? An Analysis Using GIS Techniques," Current Science, Vol. 75, No. 3, 1998, pp. 220227.

[23] Vishnu-Mittre and H. P. Gupta, "A Living Fossil Community in South Indian Hills," Current Science, Vol. 37, No. 23, 1968, pp. 671-672.

[24] R. K. Srivastava, "Seed Germination Tests of Pioneer Shola Species in Nilgiris," Annals of Forestry, Vol. 8, No. 2, 2000, pp. 293-294.

[25] P. Foster, "The Potential Negative Impacts of Global Climate Change on Tropical Montane Cloud Forests," Earth Science Reviews, Vol. 55, No. 1-2, 2001, pp. 73106. doi:10.1016/S0012-8252(01)00056-3

[26] D. H. Benzing, "Vulnerabilities of Tropical Forests to Climate Change: The Significance of Resident Epiphytes," Climatic Change, Vol. 39, No. 2-3, 1998, pp. 519-540. doi:10.1023/A:1005312307709

[27] A. M. Sugden, "Aspects of Ecology of Vascular Epiphytes in Two Colombian Cloud Forests: II. Habitat Preferences of Bromeliaceae in the Serrania de Macuira," Selbyana, Vol. 5, 1981, pp. 264-273.

[28] T. K. Abraham, "Meliolaceous and Soil Fungi and Lichen Flora of the Sholas of Munnar and Waynad," In: K. K. N. Nair, S. K. Khanduri and K. Balasubramanayam, Eds., Shola Forests of Kerala: Environment and Biodiversity, Kerala Forest Research Institute, Peechi, 2001, pp. 118-135.

[29] V. Jeeva and P. S. Ramakrishnan, "Studies on Impact of Plantation Forestry in Nilgiri Hills of the Ghats on Soil Quality and Nutrient Cycling," Tropical Ecology, Vol. 38, No. 2, 1997, pp. 215-235.

[30] E. R. C. Davidar, "A Note on the Status of the Nilgiri Tahr in the Grass Hills in the Anamalais," Journal of the Bombay Natural History Society, Vol. 68, No. 2, 1971, pp. 347-354.

[31] C. Rice, "The Behavior and Ecology of the Nilgiri Tahr (Hemitragus hylocrius Ogilby, 1838)," Ph.D. Thesis, Texas A \& M University, Texas, 1984.

[32] C. Rice, "Habitat, Population Dynamics and Conservation of the Nilgiri Tahr, Hemitragus hylocrius," Biological Conservation, Vol. 44, No. 3, 1988, pp. 137-156. doi:10.1016/0006-3207(88)90099-7

[33] C. Mishra and A. J. T. Johnsingh, "Population and Conservation Status of the Nilgiri Tahr Hemitragus hylocrius in Anamalai Hill, South India," Biological Conservation, Vol. 86, No. 2, 1998, pp. 199-206. doi:10.1016/S0006-3207(98)00004-4

[34] Daniels, "The Nilgiri Tahr: An Endemic South Indian Mountain Goat," Macmillan India, New Delhi, 2006.

[35] R. J. R. Daniels, P. S. Easa and M. Alembath, "Distribu- tion and Status of the Endangered Nilgiri Tahr," Current Science, Vol. 94, No. 1, 2008, pp. 10-11.

[36] M. Alembath and C. Rice, "Nilgiritragus Hylocrius," IUCN Red List of Threatened Species, 2008. www.iucnredlist.org

[37] K. Shanker, "The Role of Competition and Habitat in Structuring Small Mammal Communities in a Tropical Montane Forest Ecosystem in Southern India," Journal of Zoology, Vol. 253, No. 1, 2001, pp. 15-24. doi:10.1017/S0952836901000024

[38] A. A. Zarri, A. R. Rahmani, A. Singh and S. P. S. Khushwaha, "Habitat Suitability Assessment for the Endangered Nilgiri Laughing Thrush: A Multiple Logistic Regression Approach," Current Science, Vol. 94, 2008, pp. 1487 1494.

[39] K. P. Dinesh, C. Radhakrishnan and G. Bhatta, "A New Species of Nyctibatrachus Boulenger (Amphibia: Anura: Nyctibatrachidae) from the Surroundings of Bhadra Wildlife Sacntuary, Western Ghats, India," Zootaxa, Vol. 1914, 2008, pp. 45-56.

[40] A. Gioda, J. Maley, R. E. Guasp and A. A. Baladón, "Some Low Elevation Fog Forests of Dry Environments: Application to African Palaeoenvironments," In: L. S. Hamilton, J. O. Juvik and F. N. Scatena, Eds., Ecological Studies 110: Tropical Montane Cloud Forests, SpringerVerlag, New York, 1995, pp. 156-164.

[41] J. Krishnaswamy, M. C. Kiran and K. N. Ganeshaiah, "Tree Model Based Eco-Climatic Vegetation Classification and Fuzzy Mapping in Diverse Tropical Deciduous Ecosystems Using Multi-Date NDVI," International Journal of Remote Sensing, Vol. 25, No. 6, 2005, pp. 1185 1205. doi:10.1080/0143116031000149989

[42] T. P. Thomas and S. Sankar, "The Role of Sholas in Maintaining Watercourses in the High Ranges of Kerala," In: K. K. N. Nair, S. K. Khanduri and K. Balasubramanayam, Eds., Shola Forests of Kerala: Environment and Biodiversity, Kerala Forest Research Institute, Peechi, 2001, pp. 71-115.

[43] D. C. Sahoo, V. N. Sharda, M. Jayakumar, K. P. Tripathi, M. V. Padmanabhan, B. Raghunath and B. Chandran, "Hydrology of Small Watersheds in High Hills of Nilgiris," Indian Journal of Soil Conservation, Vol. 34, 2006, pp. 97-101.

[44] R. K. Gupta and K. A. Shankarnarayan, "Ecological Status of the Grasslands in South India," Tropical Ecology, Vol. 3, 1962, pp. 75-78.

[45] V. Nandakumar, P. Rajendran and K. N. Babu, "Characterization of Soils in the Sholas of Idukki and Wayanad Districts," In: K. K. N. Nair, S. K. Khanduri and K. Balasubramanayam, Eds., Shola Forests of Kerala: Environment and Biodiversity, Kerala Forest Research Institute, Peechi, 2001, pp. 25-70.

[46] S. Venkatachalam, T. Kalaiselvi, Neelakantan and S. Gunasekaran, "A Comparative Study on Soil Microflora and Nutrient Status of Sholas and Adjoining Vegetation," Indian Journal of Forestry, Vol. 30, 2007, pp. 135-140.

[47] K. V. Sankaran and M. Balasundaram, "Soil Microflora of the Sholas of Eravikulam National Park, Idukki District," 
In: K. K. N. Nair, S. K. Khanduri and K. Balasubramanayam, Eds., Shola Forests of Kerala: Environment and Biodiversity, Kerala Forest Research Institute, Peechi, 2001, pp. 151-178.

[48] R. M. May, “Thresholds and Breakpoints in Ecosystems with Multiplicity of States," Nature, Vol. 269, 1977, pp. 471-477. doi:10.1038/269471a0

[49] B. E. Beisner, D. T. Haydon and K. Cuddington, "Alternative Stable States in Ecology," Frontiers in Ecology and the Environment, Vol. 1, No. 7, 2003, pp. 376-382. doi:10.1890/1540-9295(2003)001[0376:ASSIE]2.0.CO;2

[50] V. M. Meher-Homji, "Ecological Status of the Montane Grasslands of the South Indian Hills: A Phytogeographic Reassessment," Indian Forester, Vol. 91, No. 4, 1965, pp. 210-215.

[51] V. M. Meher-Homji, "Phytogeography of the South Indian Hill Stations," Bulletin of the Torrey Botanical Club, Vol. 94, No. 4, 1967, pp. 230-242. doi:10.2307/2483901

[52] K. Balasubramanian and K. K. Kumar, "The Riddle of the Shola," Evergreen, Vol. 42, 1999, pp. 1-5.

[53] R. M. Palanna, "Eucalyptus in India," In: M. Kashio and K. White, Eds., Reports Submitted to the Regional Expert Consultation on Eucalyptus, Vol. 2, 1996. http://www.fao.org/docrep/005/ac772e/ac772e06.htm\#bm 06

[54] R. K. Srivastava, "Biotic Pressure and Entry of Exotics in Shola Grassland Ecosystem of Upper Palnis," Indian Journal of Forestry, Vol. 24, No. 3, 2001, pp. 324-327.

[55] R. Raghupathy and M. Madhu, "The Natural Grasslands of the Nilgiris: Past and Present Scenario," Range Management and Agroforestry, Vol. 28, 2007, pp. 271-273.

[56] S. C. Agrawal, U. S. Madan, S. Chinnamani and N. D. Rege, "Ecological Studies in the Nilgiris," Indian Forester, Vol. 87, No. 6, 1961, pp. 376-389.
[57] S. Seshan, "Notes from the Edge," 2006. http://www.gbsanctuary.org/articles/Notes from the Edg e.pdf

[58] T. Sekar, "Observations on Survival and Growth of Different Shola Species under a Shola Afforestation Programme in Nilgiris District, Tamil Nadu," Indian Forester, Vol. 134, No. 4, 2008, pp. 451-457.

[59] U. M. Chandrasekhara, P. K. Muraleedharan and V. Sibichan, "Disturbed Sholas of Kerala and Strategies for Its Conservation and Management," In: K. K. N. Nair, S. K. Khanduri and K. Balasubramanayam, Eds., Shola Forests of Kerala: Environment and Biodiversity, Kerala Forest Research Institute, Peechi, 2001, pp. 395-437.

[60] T. M. Brooks, R. A. Mittermeier, C. G. Mittermeier, G. A. B. da Fonseca, A. B. Rylands, W. R. Konstant, P. Flick, J. Pilgrim, S. Oldfield, G. Magin and C. Hilton-Taylor, "Habitat Loss and Extinction in the Hotspots of Biodiversity," Conservation Biology, Vol. 16, No. 4, 2002, pp. 909-923. doi:10.1046/j.1523-1739.2002.00530.x.

[61] I. M. Turner and R. T. Corlett, "The Conservation Value of Small, Isolated Fragments of Lowland Tropical Rain Forest," Trends in Ecology and Evolution, Vol. 11, No. 8, 1996, pp. 330-333. doi:10.1016/0169-5347(96)10046-X

[62] K. A. Harper, S. E. Macdonald, P. J. Burton, J. Q. Chen, K. D. Brosofske, S. C. Saunders, E. S. Euskirchen, D. Roberts, M. S. Jaiteh and P. A. Esseen, "Edge Influence on Forest Structure and Composition in Forest Fragments," Conservation Biology, Vol. 19, No. 3, 2005, pp. 768-782. doi:10.1111/j.1523-1739.2005.00045.x

[63] C. G. Gascon, B. Williamson and G. A. B. da Fonseca, "Receding Forest Edges and Vanishing Reserves," Science, Vol. 288, No. 5470, 2000, pp. 1356-1358. doi: $10.1126 /$ science. 288.5470 .1356 